\title{
Chapter 20 \\ Regulatory Frameworks for Aquaponics in the European Union
}

\author{
Tilman Reinhardt, Kyra Hoevenaars, and Alyssa Joyce
}

\begin{abstract}
This chapter provides an overview of the regulatory framework for aquaponics and the perspectives for European Union (EU) policy. Using Germany as an example, we analyze the specific regulations concerning construction and operation of aquaponic facilities and the commercialization of aquaponic products. We then show how aquaponics fits in with different EU policies and how it might contribute to EU sustainability goals. In the end, we provide some recommendations on how institutional conditions could be improved for aquaponics as an emerging technological innovation system.
\end{abstract}

Keywords Aquaponics $\cdot$ Law $\cdot$ Regulatory framework · Organic production · Animal welfare $\cdot$ Food labeling $\cdot$ Food safety policies

\subsection{Introduction}

Regulatory frameworks can have a decisive influence on the implementation of sustainable technologies. However, there are currently no specific regulations or policies for aquaponics in the European Union (EU) or most of its member states. One of the reasons perhaps is that it falls at the intersection of various larger fields (industrial aquaculture, wastewater recycling, hydroponics, urban aquaculture), wherein producers are subject to a variety of potentially disparate and conflicting regulations. The following chapter provides an overview of the regulatory

\footnotetext{
T. Reinhardt $(\bowtie)$

GFA Consulting Group, Berlin, Germany

e-mail: tilman.reinhardt@gfa-group.de

K. Hoevenaars

AquaBioTech Group, Mosta, Malta

e-mail:kyh@aquabt.com
}
A. Joyce
Department of Marine Science, University of Gothenburg, Gothenburg, Sweden
e-mail: alyssa.joyce@gu.se 
framework for aquaponics and gives some perspectives on how the development of aquaponics could be supported through EU policy. It builds on the work by Koenig et al. (2018) who have analyzed aquaponics through the theoretical framework for emerging technological innovation systems (see Bergek et al. 2008) and have shown how development pathways for this aquaponics might be influenced by institutional conditions.

The first section provides an overview of specific regulations that govern each step in development of aquaponic enterprises, i.e., construction, operation, and commercialization. It analyzes how this regulatory framework provides incentives or disincentives for individual entrepreneurs and market actors to invest in aquaponics. The second section analyzes how aquaponics fits in with different EU policies and how aquaponics can contribute to achieving EU sustainability goals. It then shows how the policies and strategies need to be redefined in order to provide better opportunities in this sector. In the third section, we draw conclusions from lessons learned in the first sections in order to provide policy recommendations.

Note: The first section summarizes the findings of a legal guideline on the feasibility of aquaponics projects in Germany. Detailed references to German regulations and case law have been left out for better readability. A German version with references to specific provisions and relevant case law is available on request from the authors. Parts of the second sub-chapter have been published in Eco cycles. Reference: Hoevenaars, K., Junge, R., Bardocz, T., and Leskovec, M. 2018. EU policies: New opportunities for aquaponics. Eco cycles 4(1): 10-15. DOI: 10.109040/ecocycles.v4il.87.

\subsection{Legal Framework for Aquaponics}

In this first section, our goal is to provide an overview of relevant regulations for the construction and operation of aquaponics facilities and the marketing of aquaponically produced products. We focus specifically on Germany, as it is impossible to extrapolate across the EU given that several important regulations, especially regarding zoning and construction, have not been harmonized across the EU. Although we focus on the German context, similar findings regarding planning law have also been reported in other countries (Joly et al. 2015).

\subsubsection{Regulations on Construction}

Aquaponic facilities must comply with various planning, building and water regulations, many of which do not fall under EU competence. In Germany, the general framework for planning and water law is harmonized at the national level, while building and local water-use regulations are determined at the state level, with urban and regional planning covered at the municipal level. 


\subsubsection{Planning Law}

Planning law regulates the use of the soil and the area-related requirements for construction projects. There is a major distinction between projects in outlying and inner urban areas.

According to Section 35 of the German Building Code, outlying areas should be kept free of buildings and are reserved for certain uses, such as agriculture or renewable energy production. Whether or not aquaponics constitutes agriculture in that sense remains an unanswered question: while courts have ruled that soilless cultivation of vegetables such as hydroponics can be considered agriculture, the case is less clear for aquaculture in indoor facilities with no connection to the natural water cycle. The definition of agriculture in Section 201 of the Building Code only recognizes fisheries. Most courts therefore view recirculatory aquaculture systems as commercial rather than agricultural enterprises. Recently, however, the administrative court of Hamburg has ruled that a plant for fish and crustacean production can be considered agricultural, if the majority of the required feed could theoretically be produced on the agricultural land, belonging to the farm regardless of the type of fish produced, or whether feed is actually produced on the farm. This exception might not be viable however in cases, where agriculturally sourced feed is not used at all. In practice, aquaculture operations were often set up in connection with biogas plants. As farmers received an additional bonus on the feed-in-tariff for cogenerating plants (i.e. plants that also produce heat), there was an incentive to install heat-absorbing aquaculture next to the biogas plant.

Additional restrictions may apply in protected areas. The construction of aquaculture facilities is seen as problematic especially adjacent to natural water bodies. Exceptions for agriculture are only available for existing facilities. This has created a number of problems in traditional fishery areas, such as Mecklenburg, where many professional fishermen have an interest and necessary skills to operate ancillary businesses such as aquaculture or aquaponics (Paetsch 2013). Given that aquaponic systems do not rely on the natural water cycle, they could provide a creative possibility for new enterprise if their benefits were assessed and recognized by relevant authorities.

However, regardless of their size, aquaponics facilities do not require an environmental impact assessment, which is only a requirement for fish farms that discharge waste into surface waters.

\subsubsection{Urban Areas}

Many proponents envision aquaponics as a possibility for urban agriculture, given that commercial facilities can be built on rooftops or unused warehouses to allow for direct delivery of products to supermarkets in urban centers. Semicommercial systems can also be located in residential areas (backyard aquaponics). Under German planning law, the permitting of a facility depends on its classification and 
the area where it is located. Commercial aquaponics farms can be classified as either commercial or horticultural businesses. As such, they are generally not allowed in residential areas. In villages and mixed-use areas, both commercial and horticultural enterprises are allowed. In commercial and industrial areas, only commercial, but not horticultural, businesses are possible.

As aquaponic facilities have comparatively few noise and odor issues, they may be allowed on an exceptional basis even in areas where they are not currently admissible under planning laws. However, obtaining an exception creates additional administrative burdens and uncertainty, which could present an obstacle to scalingup of the technology. Project-specific planning allows for cooperation with planning authorities but, in practice, is only relevant for large-scale projects due to the costs involved.

Backyard aquaponics plants might be allowed in all zones under the exception for ancillary facilities for keeping of small animals. However, ancillary facilities must be noncommercial and are interpreted differently by different district authorities. Some municipalities take a rather restrictive approach and only allow traditional forms of small animals such as dogs, chicken, pigeons, etc.

\subsubsection{Building Law}

The structural-technical requirements for buildings and administrative procedures for obtaining building permits are regulated by state-level building regulations, and while building codes follow, a so-called model building code, there can be substantial differences between states.

All construction products must comply with EU Regulation 305/2011, which requires a Declaration of Conformity to technical standards. For small wastewater treatment plants, the technical standard EN 12566 CEN applies. Rooftop systems may require special facilities for fire protection and affect minimum clearances. The static stability of the building must not be affected.

Although some of the components of an aquaponics facility, especially green houses or water tanks, do not need an individual building permit, the installation of a commercial food production system will usually require a building permit, particularly if the building has served a different purpose before. The procedure to obtain this permit might constitute a significant administrative and financial hurdle. Once obtained, however, it can also be seen as providing increased stability for outside investors given regulations will be viewed as having been met.

\subsubsection{Water Law}

Aquaponic systems do not necessarily depend on the use of surface water. Ideally water leaves an aquaponic system only via evapotranspiration or as water retained in the vegetables produced. We would argue that such facilities therefore should not require a permit under the water act or wastewater regulations. This could provide a 
major regulatory advantage compared, for instance, to traditional aquaculture or aquaculture, for which increasingly restrictive water and wastewater regulations constitute a significant obstacle to new enterprises. Savings on wastewater discharge fees present an incentive for implementing such systems.

However, it is not totally certain, if courts would follow this line of argument. Water might be considered wastewater, the moment it has been used for aquaculture. It would then be subject to the rules on wastewater disposal, which generally require disposal through centralized facilities. For example, the Higher Administrative Court of Berlin recently disallowed the use of a reed bed to clear domestic grey and blackwater, where reed was later used for energy use. The court explicitly stated that no right to multiple use of the water exists under German Water Law. In this case, a special permit for decentralized wastewater disposal would be required, and the entire aquaponics installation would have to comply with rules on wastewater disposal facilities.

The only real waste produced in aquaponic systems is filter sludge (which can be avoided, if an additional cycle for remineralization of this sludge is integrated or sludge is degraded on-site, e.g., through vermicomposting: if the filter sludge can be used on-site, no registration under the fertilizer law is required (see below)). If used outside the premises, regulations related to organic waste or sewage sludge disposal (more restrictive) apply. Filter sludge would be considered sewage sludge if the aquaponic system as a whole is considered a wastewater treatment plant: whether this applies in practice remains to be determined.

\subsubsection{Conclusions on Construction}

Fish farms present few problems in regard to noise and odor. One might therefore assume that aquaponic systems could be permitted with more ease than other animal production facilities. However, aquaponics does not fit well into the German legal framework.

As aquaponic production does not depend on the use of soil, installations may not be "agricultural enough" for outlying areas, i.e., agricultural lands. On the other hand, aquaponics might be "too agricultural" for urban areas, as urban agriculture is not considered a relevant category under German planning law. In particular, aquaponics may be generally inadmissible in commercial, industrial, and residential areas.

Commercial aquaponics facilities always require a building permit even if they are installed in pre-existing buildings which themselves do not require new building permits.

Aquaponics pioneers with very visible urban projects such as ECF or Urban Farmers seem to have coped well with the existing regulatory framework. However, planning law issues could present a relevant problem for scaling up the technology, in which case projects need to be developed in close consultation with the authorities in order to avoid future conflicts and to provide certainty for investors. 
A major regulatory advantage of aquaponics may lie in the fact that little or no wastewater is produced, thus reducing the need for wastewater removal. Wastewater permits and fees have been reported to be significant obstacles for conventional fish farmers. As wastewater fees will probably be calculated according to pollution loading in the future, they may form an even stronger incentive to think about alternative types of wastewater disposal in the future (Schendel 2016). However as the water law generally does not provide for multiple uses, a legal clarification would be very important to create certainty for producers.

Apart from this, regulatory conditions in the German water sector do not particularly favor innovation. German water law strictly adheres to the paradigm of centralized sewage and generally does not allow for decentralized recycling of material flows and other forms of "creative ecology." Unlike in the waste sector, where the regulatory framework has given strong incentives to the private sector to consider waste as a resource, regulation of wastewater sector does not create incentives for the private sector to create and implement innovative recycling technologies.

\subsubsection{Regulations on Aquaponic Production}

Aquaponic production is subject to regulations for plant and for animal production at all stages of production and processing. Under the regulatory approach "from farm to fork," many relevant regulations have been harmonized at the European level (especially through the so-called EU hygiene package). However, a few exemptions exist for small producers selling directly to customers.

\subsubsection{Hydroponic Production}

Hydroponic production is subject to comparatively few regulations: growing media need an EU approval. Using fish wastes as fertilizer requires no authorization under German fertilizer laws if those fish wastes are derived from aquaculture.

The most significant restrictions concern the use of pesticides (note: in singlecycle aquaponic systems, pesticide use is inherently limited due to the pesticides' toxicity for fish; however, pesticide use is possible in multi-cycle (decoupled) aquaponic systems where water does not return from the plants to the fish components). The German Plant Protection Act generally imposes integrated pest management which means that preventive measures and the promotion of natural response mechanisms (e.g., suitable locations, substrates, varieties, seeds and fertilizers, as well as physical and biological control measures) have to be given priority before pesticide use. The use of invasive species for biological pest control is prohibited.

Pesticides may only be used by qualified personnel. Only pesticides that are approved under European regulation (EC) 1107/2009 may be used. Regulation (EC) 1107/2009 also includes rules on the use, storage, and disposal of pesticides. 
Before harvesting, certain waiting periods must be observed. Residues in vegetables may not exceed certain maximum residue levels (MRLs). A free online database of MRLs is provided by the Directorate General for Health and Consumers (DG SANCO).

\subsubsection{Aquaculture}

In contrast to horticulture, aquaculture is carefully regulated through many different regulations. However a distinct aquaculture law neither exists at the national nor European level, and state-level fishery laws only regulate fishing in natural water bodies.

\subsubsection{Cultivation of Non-native Species}

The most commonly cultivated fish in aquaponics systems are tropical species such as tilapia or African catfish. However, the complex rules of Regulation (EC) 708/ 2007 concerning the use of alien species in aquaculture generally do not apply to closed recirculating aquaculture facilities (registered in a directory of recirculating aquaculture facilities). Some countries (e.g., Spain and Portugal, but not Germany or France), however, have decided to ban some types of exotic fish outright, which also affects the possibilities of cultivating them in closed facilities.

\subsubsection{Regulation on Fish Diseases in Aquaculture}

All aquaculture producers are subject to German regulation on fish diseases, which implements European Directive 2006/88/EC on animal health requirements for aquaculture animals and products thereof and on the prevention and control of certain diseases in aquatic animals (Ministry of Agriculture of Bavaria 2010). Under this regulation, aquaculture operations generally require permits by the local veterinary authorities. However, producers who only sell small quantities of fish directly to consumers or to local retailers only need to register certain information such as name and address, location and size of the operation, source of water supply, amount of fish held, and fish species.

Most importantly, the regulation on fish diseases imposes a duty on operators of fish farms to inform the local veterinary authorities in the event of a suspected disease outbreak. Veterinary authorities may then implement necessary control measures, which in some cases may involve destroying the entire stock should there be concern of disease spread.

Note: European animal health law, which was previously regulated relatively confusing in some 400 individual acts, is unified under Regulation (EU) 2016/429. However, the regulation only enters into force only on 21 April 2021. The content concerning fish diseases will not change (Art. 173 et seq. Regulation (EU) 2016/429). 


\subsubsection{Regulations on Animal Feed}

The ability to source sustainable animal feeds is a key prerequisite for sustainable food production. In comparison to land animals, fish have a much better feed conversion rate; however, many higher trophic-level fish species require a certain portion of their feed to be derived from protein and fat from animal origin (e.g., fish meal). Feeding insects or insect larvae to fish is often seen as a possible way to increase the sustainability of aquaculture. Insects can be cultivated using waste organic nutrients, in some cases derived from animal wastes, including offal.

Animals for human consumption however must not be fed proteins of animal origin (with the exception of fish protein) according to Regulation (EC) 999/2001, which was implemented in reaction to BSE crisis in the 1990s. While it is sometimes argued that the ban of feed sources from animal protein should not apply to insects, which were not considered as potential feed sources in 2001, the use of insect feed is disallowed in practice by the German veterinary authorities.

Currently, some pet food is already produced using insect proteins (e.g., dog food from Brandenburg-based start-up Tenetrio). Given the increased interest in using insect protein for animal feed, several legislative changes have been made at the European level to allow for the feeding of insect protein based on adaptations to the existing regulatory frameworks (Smith and Pryor 2015). Since 2017, a so-called risk profile of the European Food Safety Authority (EFSA) is available (EFSA Journal 2015; 13 (10): 4257). Insects may be allowed as feed in aquaculture from 2018. However, some restrictions remain in place: in particular insects to be used as animal feed must not have fed on human or ruminant waste products. Insect production also poses some addition open regulatory questions, e.g., welfare issues regarding standard procedures for killing.

\subsubsection{Regulation on Animal Welfare}

Compared to other livestock, there are far few animal welfare regulations (Chap. 17) for handling and killing of fish. Although it is generally accepted that fish can feel pain, there is a lack of scientific evidence to justify restrictions for animal welfare (Studer/Kalkınç 2001). On the European level, there are only a few non-binding recommendations initiated in 2006 by the European Commission. According to Article 22 of these recommendations, a revised version based on new scientific evidence was anticipated by 2011 , but to date EFSA has only published speciesspecific recommendations for certain types of fish, as well as special provisions on the transport of fish. Article 25 lit f - h. and Annex XIII of Regulation (EC) 889/2008 on organic production and labeling of organic products also contains species-specific rules on stocking density. As organic labeling is not available for fish from recirculatory aquaculture (see below), these rules are not relevant for aquaponics. Most private certification standards also do not consider animal welfare aspects (Stamer 2009). 
Under Section 11 of the German law on animal welfare, keeping animals for commercial purposes generally requires a permit. To obtain this permit, one must demonstrate appropriate training or previous professional experience in animal husbandry and show that the production system provides adequate nutritional and housing facilities (Windstoßer 2011). Operations are considered commercial when expected sales exceed $€ 2000$ per year.

According to Section 11 para 1 no. 8 TierSchG, no permit is needed for the commercial keeping of "farm animals." Whether fish can be considered farm animals in this sense is unclear. Exceptions to the animal welfare law are generally interpreted strictly: species are only considered farm animals if the necessary skills for keeping them can be acquired anytime, anywhere and there exists sufficient experience regarding the keeping of a species (Windstoßer 2011). This may not be the case for some types of tropical fish that differ fundamentally from native species (e.g., Arapaima, whose use in aquaculture is currently being explored at IGB Berlin).

The Administrative Court of Cologne has recently examined animal welfare aspects when ruling on the admissibility of a so-called fish spa, where Kangal fish were kept with the goal of using them to clean human feet. Operators of this fish spa were able to prove through veterinary reports that animal welfare was not being compromised and as such, a permit was granted.

\subsubsection{Regulation on Fish Slaughter}

Animal slaughter is regulated by European Regulation (EU) 1099/2009 as well as the German Decree of 20.12. 2012 (Federal Law Gazette I, p. 2982).

According to Recital 11 of Regulation (EU) 1099/2009, fish are physiologically different from terrestrial animals, and thus farmed fish can be slaughtered and killed with fewer animal welfare restrictions, in this case with specific implications for the inspection process. Furthermore, research on the stunning of fish is far less developed than for other farmed species. Separate standards should be established on the protection of fish at killing. Therefore, provisions applicable to fish should, at present, be limited to the key principle.

Under the general rule of Art. 3 Section 1 of Regulation (EU) 1099/2009, animals shall be spared any avoidable pain, distress, or suffering during their killing and related operations. However, there is no explicit obligation to stun fish before slaughter. That said, EU member states may maintain or adopt national rules aimed at ensuring more extensive protection of animals at the time of killing than those contained in this Regulation (Art. 26).

For instance, in Germany, slaughtering fish is subject to stricter conditions than those imposed by Regulation (EU) 1099/2009: as such, all types of fish except flatfish and eel have to be stunned before killing. Those doing the killing need a certificate of competence. Appropriate stunning methods may differ from species to species, with implications for producers: in Switzerland, aquaculture producer reportedly had to close his operation as the local veterinary authorities did not 
allow stunning using the ice water method, which he was employing. Defining appropriate killing methods for different fish species is the subject of an ongoing research project funded by BLE at the University of Veterinary Medicine Hannover and may lead to more restrictive regulations in the future.

Animal welfare aspects may also restrict certain forms of marketing and selling of fish. For example, the Higher Administrative Court of Bremen has forbidden placing farmed fish into ponds, from which were to be fished by recreational anglers as this was considered "unnecessarily harmful."

\subsubsection{Regulation on Vocational Training of Fish Farmers}

The German federal regulation on the vocational training of fish farmers does not mention aquaponics. Some private companies offer courses on aquaponics on the German market. However, it is not clear whether such courses are considered sufficient to obtain necessary permits (e.g., for pesticide use, commercial keeping of animals, slaughtering, etc.).

\subsubsection{Hygiene Law}

Hygiene law is harmonized on the European level through Regulations (EC) 852/ $2004,853 / 2004$, and 854/2004.

As a general rule, all food business operators, regardless of product, have to comply with EU hygiene law. As such, they must comply with the general standards of hygiene and management in Annex I and II of Regulation 852/2004, including basic requirements on production processes and personal hygiene, as well as appropriate waste treatment. They have to keep a register of the origin of animal feeds, as well as the use of pesticides and veterinary drugs. Measures to avoid risks must be documented in an appropriate manner.

According to Annex II Chapter IX no. 3 of Regulation (EC) 852/2004, food has to be protected against any contamination at all stages of production, processing, and distribution. Under Regulation (EC) No 178/2002, contamination may refer to any biological, chemical, or physical agent in a food or a condition of a foodstuff, which can cause adverse health effects. Food business operators must implement and maintain a HACCP (hazard analysis and critical control points) system, which has to be certified by accredited certification bodies. Details are agreed upon with local authorities.

EU hygiene legislation does not apply to the direct supply of small quantities of primary products to the final consumer or to local retail establishments. Small amounts are defined as household amounts for direct delivery to consumers or for local retail as for usual daily consumption. Primary production in the case of fish includes catching, slaughtering, bleeding, heading, gutting, removing fins, refrigeration, and wrapping. Activities such as flash-freezing, filleting, vacuum packing, or smoking will result in the fish no longer being considered primary local production. 
Under German law certain restrictions on food hygiene exist however even for direct local food suppliers (Annex 1 LMHV).

Registration or authorization requirements in Regulation (EC) No 853/2004 depend on volume and type of processing. No registration or authorization is required for the supply of primary products in household quantities directly at the place of production, processing, or storage (including nearby markets). It is also possible to supply retail establishments (supermarkets, restaurants), consumers, or restaurants within a radius of $100 \mathrm{~km}$. If primary products are delivered to end consumers, or to restaurants in larger quantities, the company must register and demonstrate their ability to meet food hygiene requirements. If more than one-third of the animal-derived products are sold to retail outlets outside the region (radius of $100 \mathrm{~km}$ ), a public health license is also required.

\subsubsection{Conclusions on Production}

The legal requirements for aquaponic production are not higher than for the production of fish or vegetables. However, the large number of applicable laws reflects the complexity of aquaponics.

Compared to livestock farming, aquaculture may appear less regulated, especially in the area of animal welfare law. However, legal "gray areas" and the corresponding uncertainty are not always to the advantage of producers. Without established administrative practices, there is a considerable risk of conflicts (c.f. for the cited case in Switzerland, where an aquaculture operation was shut down, because the producer was not allowed to kill the fish in specific ways). In addition, the large number of applicable regulations can be burdensome, especially where European and national regulations coexist (e.g., on animal welfare or hygiene). As there is no harmonized law on aquaculture in Germany, producers need various permits from different authorities. Authorities often have little experience with nontraditional aquaculture, and as such, uncertain administrative requirements can be discouraging for entrepreneurs. Given the relative newness of commercial aquaponics, potential producers are strongly advised to contact local authorities at an early stage. In the case of larger, commercial plants, operators should probably contact veterinary and hygiene authorities prior to beginning construction.

The increasingly strict requirements of European hygiene laws can also constitute a significant burden, especially for small enterprises who wish to market directly to consumers or local restaurants (Schulz et al. 2013). However, whether exemptions for direct sellers are of practical help to aquaponic operators remains to be determined. The few existing aquaponics facilities in Germany currently demonstrate the necessity for producers to depend on a variety of sales channels and the need to create various forms of ancillary revenue (guided tours, secondary processing, cooking classes, etc.). Exemptions for direct selling therefore may become irrelevant if hygiene standards have to be met for other reasons. 


\subsubsection{Commercialization}

Commercialization of aquaponic products is affected by different regulatory regimes. Hygiene regulations not only concern food production but also food retailing (see above). Business and tax laws, labeling regulations, or special certifications, such as the EU organic labeling regulations, may also be relevant.

\subsubsection{Business and Tax Law}

Agriculture is privileged in a number of ways under German business law: the marketing of self-produced agricultural products through farm stores, from the field or from a market stall, is not considered a business under German law and therefore requires no registration. This exception extends to the first stage of processing, i.e., cleaning and gutting, filleting and smoking in the case of fish, or in the case of fruits and vegetables, peeling, chopping, cooking, as well as the production of juices and wine (Chamber of Agriculture Rhineland-Palatinate 2015). Direct selling of agricultural products is also exempt from legal restrictions on opening times and the Sunday sales ban. Considering the low costs and low administrative requirements of a business registration, however, these privileges may not constitute a relevant advantage.

Tax privileges for agricultural production may be of greater practical importance. Regardless of size, aquaculture operations are subject to so-called average-rate VAT taxation, which offers a greatly reduced effective rate of value-added-tax that enables local producers to sell at more competitive prices relative to international imports.

In the income tax code, there are considerable privileges for "small farms" (i.e., turnover $<500,000 €$, farm size $<20$ hectares without special uses). If certain area limits are respected $\left(600 \mathrm{~m}^{2}\right.$ of under-glass vegetables, $1600 \mathrm{~m}^{2}$ of ponds) income from aquaculture and vegetable growing is not taxed at all; even if the cultivated areas exceed these limits, effective tax rates are extremely low. As a result, the operation of aquaponics for small farmers might essentially be considered tax-free.

\subsubsection{Regulations on Food Labeling}

Rules on food labeling have largely been harmonized at the European level through European Regulation 1169/2011 on food packaging. Besides the formal rules, however, voluntary labeling standards play an even bigger role in the marketplace (see Sodano et al. 2008). In the case of the EU organic label, the voluntary standard is also regulated by law. In other cases, the rules of private certification schemes have to be followed. 


\subsubsection{General Labeling Rules}

The general rules for selling packaged products are laid down in European Regulation 1169/2011 (e.g., the duty to include a list of ingredients, etc.). As a general rule, Art. 7 para. 1 Regulation (EU) 1169/2011 bans misleading claims on food packaging.

In addition to these general rules, Regulation (EU) 1379/2013 contains special rules on consumer information regarding aquaculture products. For example, under Art. 38 of Regulation (EU) 1379/2013, the member state or the third country, in which the aquaculture product has acquired more than half of its final weight, must be correctly named on the label.

\subsubsection{EU Organic Regulation}

Products from aquaponics are not eligible for labeling as organic under the current EU regulations for organic products. Article 4, Regulation (EC) 889/2008, explicitly forbids the use of hydroponics in organic farming. Recital 4 states that organic/ biological crop production is based on the principle that plants obtain their food primarily from the soil ecosystem. For aquaculture products, Art. 25 g Regulation (EC) 710/2009 forbids the use of closed-circuit systems, and according to Recital 11 of Regulation (EC) 710/2009, this follows from the principle that organic production should be as close to nature as possible. These rules will not change in the new EU organic labeling regulation adopted in 2018, which will enter into force in 2021.

Laws preventing organic certification of hydroponic products are not shared by countries such as the USA and Australia, where hydroponic/aquaponic products can be certified organic.

\subsubsection{Private Labels}

Although there are currently no specific certification schemes for aquaponics, a number of certifications are available for aquaculture. Private certifications are usually "awarded" for a certain period of time, if private certain certification bodies can verify that productions comply with the criteria defined by their labeling standard. Private labeling schemes are usually purely contractual, with standards set by private institutions, which are subject only to general legal obligations (e.g., antitrust law). While the design of certification systems is increasingly in the purview of European legislation, including certification for aquaculture (cf. Commission report on options with regard to the allocation of EU eco-label for fishery and aquaculture products from 05.18.2016, COM see. (2016) 263 final), no concrete obligations for labeling schemes for aquaculture exist to date under European law. 
Labeling schemes are essential, especially in business-to-business (B2B) relationships between producers/processors and retailers. Increasingly, however, certification also plays a role in marketing to final consumers (B2C). Beside qualitative aspects, B2C often certify compliance with certain environmental and social standards. Certification schemes can vary greatly in standards, verification modalities, and cost.

Among existing certification schemes, the Aquaculture Stewardship Council (ASC) may be most relevant for aquaponics producers. This certification has been awarded by the Aquaculture Stewardship Council (ASC) since 2010, as a complement to the better-known Marine Stewardship Council (MSC) program. The ASC is a formally independent, private, nonprofit organization initiated by the WWF and responsible for developing quality, ethical, and sustainability standards with scientific input. Private certification companies (e.g., in Germany TÜV NORD) are accredited by the ASC to confirm compliance with these standards. ASC standards currently exist for the following species: abalone, trout, shrimp, salmon, clams, catfish, and tilapia. Standards, audit manuals, and audit preparation checklists are freely available on the ASC website, and standardized procedures have also been made public. The ASC standard has different priorities, for instance, for the EU organic label (e.g., GMO-based animal feed is not prohibited under ASC).

Aquaculture certifications are also offered by the Cologne-based quality assurance and certification system GLOBALG.A.P. While GLOBALG.A.P. usually focuses on B2B certification for quality assurance in the food retail sector, a consumer label called GGN is also awarded for farmed fish and is often used, for instance, for fish that are not eligible for organic certification because they are wild caught or produced in aquaponics. Consumers can access information via www.myfish.info.

\subsubsection{Market Organizations}

Regulation (EU) 1379/2013 on the common organization of markets in fishery and aquaculture products contains detailed rules on the establishment, recognition, objectives, and actions of professional organizations, i.e., producer organizations (Art. 6 ff.) and inter-branch organizations (Art. 11 ff.).

According to Article 8 (3) of Regulation (EU) 1379/2013, producer organizations in the field of aquaculture may, inter alia, make use of the following measures: promoting sustainable aquaculture, notably in terms of environmental protection, animal health, and animal welfare; collecting information on marketed products, including economic information on sales and production forecasts; collecting environmental information; planning the management of aquaculture activities of their members; and supporting programs for professionals to promote sustainable aquaculture products. According to Article 15 of Regulation 1379/2013, producers' organizations may also receive financial support from the EU's maritime and fisheries policies. 
Measures taken by inter-branch organizations include, for example, the promotion of aquaculture products of the European Union in a nondiscriminatory manner by using, for example, certification and designations of origin, quality seals, geographical designations, traditional specialties guaranteed, and sustainability merits (Art. 13 lit a Regulation 1379/2013). Inter-branch organizations may adopt rules for the production and marketing of aquaculture products which are stricter than the provisions of European Union or national law (Art. 13 lit c Regulation 1379/2013).

Recognition as a producer organization can have far-reaching consequences; member states may, under certain conditions, make the rules agreed upon within a producer organization binding on all producers in the area (Art. 22 Regulation 1379/ 2013). Also, agreements, decisions, or concerted practices agreed upon within an inter-branch organization can be made binding on other operators (Article 23 of Regulation 1379/2013). According to Art. 41 VO 1379/2013, producer organizations are largely exempt from antitrust law.

So far, there are no professional associations in the field of aquaponics in the European Association of Fish Producers Organizations (EAPO). However, in 2018 an association for aquaponics has been founded in Germany (http://bundesverbandaquaponik.de/), and an EU Aquaponics Association (EUAA) based in Vienna has been founded at the initiative of several stakeholders assembled in the EU COST Action.

\subsubsection{Conclusions on Commercialization}

In terms of business and tax law, there are various privileges that could theoretically be exploited by aquaponics operators. Tax benefits could be especially interesting for outside investors. However, it remains to be seen whether certain conditions regarding the legal form of an enterprise and required investment volumes prevent operators from claiming these benefits. So far, the best-known urban aquaponics projects in Germany have not been profitable, so the issue of paying taxes has not arisen.

Under business and tax laws, the thresholds for privileges of small-scale installations and direct marketers are not congruent with the thresholds under hygiene law. A detailed review of operating and marketing concepts is therefore required in each individual case.

The EU organic label is currently out of the question for aquaponic products. However, there are increasingly private opportunities for certification.

\subsection{Aquaponics and EU Policies}

National policies can only be analyzed for each individual country. We therefore concentrate on relevant EU policies. 


\subsubsection{Overview of Relevant EU Policies}

The Common Fisheries Policy (CFP) and the Common Agricultural Policy (CAP) apply to the aquaculture and hydroponics components of aquaponics, respectively (European Commission 2012, European Commission 2013). Policies on food safety, animal health and welfare, plant health, and the environment (waste and water) also apply.

\subsubsection{Common Agricultural Policy}

The Rural Development Policy, also referred to as the second pillar of CAP, focuses on increasing competitiveness and promoting innovation (Ragonnaud 2017). Each member state has at least one rural development program. Most countries have set goals to provide training, restructure and modernize existing farms, set up new farms, and reduce emissions. Measures against excessive use of inorganic fertilizers were introduced in the CAP as well as environmental policies and are regulated through the EU's Nitrates Directive (Directive 91/676/EEC 1991) and the Water Framework Directive (WFD).

\subsubsection{Common Fisheries Policy}

The CFP reform and strategic guidelines for the sustainable development of EU aquaculture were issued by the Commission to assist EU countries and stakeholders with challenges that the sector is facing. The emphasis is on facilitating implementation of the Water Framework Directive as it relates to aquaculture (European Commission 2013).

The CFP requires the development of a multiannual national strategic plan in each member state with strategies to promote and develop the aquaculture sector (European Commission 2016). Taking into account their different histories and cultivated species, each member state can support their existing aquaculture technologies but also develop new ones, such as aquaponics. This strategy should lead to an increase in production and reductions in dependence on imports. The main actions planned by member states are simplification of administrative procedures, coordinated spatial planning, enhancement of competitiveness, and promotion of research and development.

In the framework of the CFP, an Aquaculture Advisory Council (AAC) has been established. The main objective of the AAC is to provide advice and recommendations to European institutions and member states on issues related to sustainable development of the aquaculture sector (Sheil 2013).

A goal of both CFP and CAP is to increase competitiveness and sustainability of aquaculture and agriculture, respectively (Massot 2017). One of the objectives in the CFP is to exploit competitive advantage by obtaining high-quality, health, and environmental production standards. 


\subsubsection{EU Food Safety Policy}

The goal of the food safety policy of the EU is to ensure safe and nutritious food from healthy animals and plants while supporting the food industry (European Commission 2014). The integrated food safety policy also includes animal welfare and plant health. In the strategy for animal welfare, there is an action on the welfare of farmed fish; however, there are no specific rules in place (European Commission 2012).

\subsubsection{Environmental Policies}

Environmental impacts of aquaculture are regulated under a range of EU legal requirements including water quality, biodiversity, and pollution. Environmental policies relevant for aquaponic operators are the strategy on the prevention and recycling of waste (European Commission 2011) and the seventh Environment Action Program (EAP) under the EU Environmental Policy (European Union 2014).

\subsubsection{How Aquaponics Can Contribute to Goals in EU Policies and Strategies}

Aquaponics can contribute to the development goals mentioned in these policies, with the main factors being reductions of water use and waste from fish production through nutrient recycling. Discharged water is converted into a resource and solid wastes can be upgraded as plant fertilizers. Because modern aquaponics is based on recirculating aquaculture systems, these operations are relatively independent of their location and can contribute to regional food production and value chains even in urban areas. Open aquaculture systems have constraints: water resource use, pollution, localized reduction in benthic biodiversity, significant dredging of water bodies, physical modification of land, changes in water flow, and introduction of alien species (European Union 2016). However, mitigation of most constraints is possible in aquaponic systems. Compared to hydroponic systems, aquaponics reduces the use of mineral, often unsustainably mined, fertilizers.

One of the priorities in the strategic guidelines on aquaculture is to improve access to space and water (European Commission 2013). Competition among different stakeholders and often strict environmental rules limit the further development of open aquaculture systems inside the EU. However, aquaponic systems can be located almost anywhere, including deserts and degraded soil and salty, sandy islands, since a closed-loop uses a minimum of water. Therefore, it can utilize space that is not suitable for other food production systems, like rooftops, abandoned industrial sites, and generally nonarable or contaminated land. Since aquaponics reuses $90-95 \%$ of the water, it relies much less on water availability compared to other systems like open aquaculture, hydroponics, and irrigation agriculture. 
Just like in recirculating aquaculture systems, a benefit of larger commercial aquaponics systems is the possibility to obtain a high level of biosecurity, in which environmental conditions can be fully controlled ensuring a healthy environment for the fish (Badiola et al. 2012), thus minimizing the risk for diseases and parasite outbreaks (Yanong and Erlacher-Reid 2012). Because of the higher control on production, risk of losses is lower (Yanong and Erlacher-Reid 2012), which can provide aquaponic farmers with a competitive advantage over traditional farmers. On the other hand, using one nitrogen source to culture two products (Somerville et al. 2014) increases the investment risk as both fish and plant production must be maximized in order to make a profit. However, if this is done successfully, combined with the positive perceptions in Western markets of more environmentally friendly products, high revenues can be achieved (Somerville et al. 2014).

An objective in the strategy on the prevention and recycling of waste (European Commission 2011) includes introducing life-cycle thinking that considers a range of environmental impacts. It mentions that the prevention of waste is the priority, followed by reuse, recycling, recovery, and last disposal. Also, one of the priority areas in the seventh EAP targets transformation of the EU into a resource-efficient, low-carbon economy with a special focus on using waste as a resource (European Union 2014). Aquaponics systems minimize waste output (Goddek et al. 2015). The water in aquaponics systems is recirculated, thus wastewater is minimized. By using the fish process water for plant nutrition, organic waste from aquaculture is reused in the hydroponics component of the aquaponics system. The solid waste produced in an aquaponics system can be mineralized and returned to the system or utilized as compost for soil-based agriculture. Aquaponics also promotes local food production, thereby minimizing transport costs. Lastly, placing aquaponics farms in urban settings, it can provide ecological value in cities and play a role in adaptation to climate change.

\subsubsection{Financial Support by the EU}

The Seventh Framework Program (under the Multiannual Financial Framework of the European Commission) funded a couple of projects related to aquaponics. The EU Framework Program Horizon 2020 (challenge 2 "Food security, sustainable agriculture and forestry, marine and maritime and inland water research, and the bioeconomy" and challenge 5 "Climate action, environment, resource efficiency and raw materials") provides funding to several aquaponics initiatives including COST (European Cooperation in Science and Technology) Action FA1305 "The EU Aquaponics Hub: Realising Sustainable Integrated Fish and Vegetable Production for the EU" to promote innovation and capacity building by a network of researchers and commercial aquaponics companies.

Other possible funding opportunities for aquaponic development projects under the Multiannual Financial Framework of the European Commission include the European Innovation Partnership Agricultural Productivity and Sustainability 
(EIP-AGRI), a long term EU-Africa research and innovation partnership on food and nutrition security and sustainable agriculture (LEAP-AGRI), the European Innovation Council pilot Small and Medium-Sized Enterprises Instrument (SME Instrument), the ERANET MED initiative Partnership on Research and Innovation in the Mediterranean Area (PRIMA), and the European Maritime and Fisheries Fund (EMFF). The EMFF can support research institutions and universities as well as companies; however, it requires different rates of co-funding.

\subsubsection{Conclusions on the Overall EU Policy Landscape}

None of the EU policies and guidelines so far explicitly mentions aquaponics. According to DG MARE, regulations on aquaponics need to be resolved within the individual member states (COST Action FA1305 2017), e.g., involving action resulting from the respective national strategic plans. Even though there is no explicit EU framework for aquaponics, it is an innovative agricultural system that can contribute to many priorities set through EU policies and strategies. EU support through financial measures is assisting further development of the technology. However, this mostly targets research projects, while the sector also needs assistance for commercial development through support of proof-of-concept projects. As a matter of fact, there are so far very few successful commercial aquaponics systems operating in the EU, so currently, there might not be a necessity for an aquaponics policy. However, ultimately recognizing and covering the technology in existing policies will be beneficial for the development of the sector.

\subsection{Overall Conclusions and Policy Recommendations}

Aquaponics is not only at the nexus of different technologies but also at the nexus of different regulatory and policy fields. While it may provide solutions to various sustainability goals, it seems to fall in the cracks between established legal and political categories. To add to the complexity, the development of aquaponics is affected by regulation from different levels of government. For example, facilitation of urban agriculture has to come from the national or even subnational level, as the EU has no competence in planning law. Major regulatory incentives for the implementation of aquaponic technology could probably be set in water law, which falls under national and EU competence. Implementation of aquaponics could gain significant traction, if aquaculture operations had the obligation or at least financial incentives to deal with wastewater themselves. However this would require a major change in the current regulatory approach.

In the theory on technological innovation systems (TIS), an "institutional alignment" in the formative phase of a TIS is seen as critical. Only if institutions are sufficiently aligned will markets form and provide space for entrepreneurial 
experimentation to determine commercially viable paths for implementing the technology (Bergek et al. 2008). For institutional alignment to take place, the proponents of the new technology need to be sufficiently organized to contribute to a process of "legitimation" of their technology (Koenig et al. 2018).

As a first step, we therefore recommend that proponents reach out, create, and strengthen links to various stakeholders and among themselves in the relevant professional communities in order to build a case for making aquaponics a legitimate activity. The newly founded EU Aquaponics Association could play a large role in this process. A further step could be the development of certifiable standards in cooperation with established certification systems. With the current lack of a coherent legal framework, such standards would give producers, consumers, administrators, and other relevant parties (e.g., outside investors or insurers, who doubt the safety of aquaponic products) a framework for understanding quality and risks. Such standards could be adapted flexibly to the practical demands of producers. Eventually formal regulations could build on such standards, as they do in other regulatory domains.

On the European level, stakeholders should push for greater recognition of the potential benefits of aquaponics in different policy areas. The EU must provide critical financial support, since commercial implementation of aquaponics is still in its infancy. The EU should also provide a forum for the exchange of best practices for regulatory issues such as construction and wastewater that fall under the competence of member states.

On the national level, stakeholders have to push for a coherent and accessible regulatory framework that is adapted to the realities of modern aquaculture and sets incentives for "creative ecology." Significant advances might even be realized on a subnational level, where political resistance may be overcome more easily. Further research should concentrate on the regulatory strategies of different countries to identify best practices.

\section{References}

Badiola M, Mendiola D, Bostock J (2012) Recirculating Aquaculture Systems (RAS) analysis: main issues on management and future challenges. Aquac Eng 51:26-35. https://doi.org/10. 1016/j.aquaeng.2012.07.004

Bergek A, Jacobsson S, Carlsson B, Lindmark S, Rickne A (2008) Analyzing the functional dynamics of technological innovation systems: a scheme of analysis. Res Policy 3(37):407-429

COST Action FA1305 (2017) Report on a Workshop with representatives from DG MARE, DG AGRI and DG RTD. 5 p. Available online: http://euaquaponicshub.com/hub/wp-content/ uploads/2017/07/Workshop-notes.pdf

Directive 91/676/EEC (1991) Council Directive of 12 December 1991 concerning the protection of waters against pollution caused by nitrates from agricultural sources. Off J Eur Communities 8 p. Available online: http://eur-lex.europa.eu/legal-content/EN/TXT/?uri=celex:31991L0676

European Commission (2011) Report from the commission to the European parliament, the council, the European economic and social committee and the committee of the regions on the Thematic Strategy on the Prevention and Recycling of Waste. $11 \mathrm{p}$ 
European Commission (2012) Communication from the commission to the European Parliament, the council, the European Economic and social committee and the committee on the European Union Strategy for the Protection and Welfare of Animals 2012-2015. 12 p. Available online: https://ec.europa.eu/food/sites/food/files/animals/docs/aw_eu_strategy_19012012_en.pdf

European Commission (2013) Communication from the commission to the European Parliament, the council, the European Economic and social committee and the committee of the regions; Strategic guidelines for the sustainable development of EU aquaculture. 12 p. Available online: http://eur-lex.europa.eu/legal-content/EN/TXT/PDF/?uri=CELEX:52013DC0229\&from=EN

European Commission (2014) The European Union explained -food safety. 16 p. Available online: https://europa.eu/european-union/topics/food-safety_en

European Commission (2016) Summary of the 27 Multiannual national aquaculture plans. $12 \mathrm{p}$. Available online: https://ec.europa.eu/fisheries/sites/fisheries/files/docs/body/27-multiannualnational-aquaculture-plans-summary_en.pdf

European Union (2012) The common agricultural policy-a story to be continued. Publicaetions Office of the European Union. 23 p. Available online: http://ec.europa.eu/agriculture/50-yearsof-cap/files/history/history_book_lr_en.pdf

European Union (2014) Living well, within the limits of our planet, 7th EAP-The new general Union Environment Action Programme to 2020. 4 p. Available online: http://ec.europa.eu/ environment/pubs/pdf/factsheets/7eap/en.pdf

European Union (2016) Commission staff working document on the application of the Water Framework Directive (WFD) and the Marine Strategy Framework Directive (MSFD) in relation to aquaculture. 36 p. Available online: http://ec.europa.eu/environment/marine/pdf/SWD_ 2016_178.pdf

Goddek S, Delaide B, Mankasingh U, Ragnarsdottir KV, Jijakli H, Thorarinsdottir R (2015) Challenges of sustainable and commercial aquaponics. Sustainability 7:4199-4224. https:// doi.org/10.3390/su7044199

Joly A, Junge R, Bardocz T (2015) Aquaponics business in Europe: some legal obstacles and solutions. Ecocycles 1(2):3-5. https://doi.org/10.19040/ecocycles.v1i2.30

König B, Janker J, Reinhardt T, Villarroel M, Junge R (2018) Analysis of aquaponics as an emerging technological innovation system. J Clean Prod 180:232-243

Massot A (2017) The Common Agricultural Policy (CAP) and the treaty. Fact sheets on the European Union. European Parliament. Available online: http://www.europarl.europa.eu/ atyourservice/en/displayFtu.html?ftuId=FTU_3.2.1.html

Paetsch U (2013) Jahresfischereitag und Jahreshauptversammlung des Landesverbandes der Binnenfischer MV e.V. - Güstrow, 25. Februar 2013: Bericht des Präsidiums für das Jahr 2012, Fischerei \& Fischmarkt in MV 2/2013, 6-9

Ragonnaud G (2017) Second pillar of the CAP: rural development policy. Fact sheets on the European Union. European parliament. 4 p. Available online: http://www.europarl.europa.eu/ atyourservice/en/displayFtu.html?ftuId=FTU_3.2.6.html

Schulz K, Weith T, Bokelmann W, Petzke N (2013) Urbane Landwirtschaft und "Green Production" als Teil eines nachhaltigen Landmanagements. Discussion paper 6. Müncheberg

Schendel F (2016) Abwasserabgabe - wann kommt eine Reform? Natur und Recht:166-171

Sheil S (2013) Strategic guidelines for EU aquaculture. Library briefing. 6 p. Available online: http://www.europarl.europa.eu/eplibrary/Strategic-guidelines-for-aquaculture-in-the-EU.pdf. Accessed on 05 Oct 2017

Somerville C, Cohen M, Puntanella E, Stankus A, Lovatelli A (2014) Small-scale aquaponic food production. FAO Fisheries and Aquaculture Technical paper 589. 288 p. Available online: http://www.fao.org/3/a-i4021e.pdf

Smith R, Pryor R (2015) Deliverable 5.1 - Mapping Exercise Report with regard to current Legislation \& Regulation: Europe and Africa \& China, 2015

Sodano V, Hingley M, Lindgreen A (2008) The usefulness of social capital in assessing the welfare effects of private and third-party certification standards: trust and networks. Br Food J 110 (4/5):493-513 
Stamer A (2009) Betäubungs- \& Schlachtmethoden für Speisefische, FiBL, Available online: http:// orgprints.org/16511/1/stamer-2009-literaturstudie_fischschlachtung-FiBL_Bericht.pdf

Windstoßer C (2011) Rechtliche Voraussetzungen für die Errichtung von Kreislaufanlagen, Präsentation im Rahmen des Seminars "Fischproduktion in Kreislaufanlagen - Prinzipien, Wirtschaftlichkeit, Zukunft" FFS Baden-Württemberg Available online: http://www. landwirtschaft-bw.info/pb/site/lel/get/documents/MLR.LEL/PB5Documents/lazbw_ffs/ Windsto\%C3\%9Fer_Rechtliche\%20Voraussetzung.pdf

Yanong RPE, Erlacher-Reid C (2012) Biosecurity in aquaculture, Part 1: An overview. SRAC Publication No. 4707

Open Access This chapter is licensed under the terms of the Creative Commons Attribution 4.0 International License (http://creativecommons.org/licenses/by/4.0/), which permits use, sharing, adaptation, distribution and reproduction in any medium or format, as long as you give appropriate credit to the original author(s) and the source, provide a link to the Creative Commons licence and indicate if changes were made.

The images or other third party material in this chapter are included in the chapter's Creative Commons licence, unless indicated otherwise in a credit line to the material. If material is not included in the chapter's Creative Commons licence and your intended use is not permitted by statutory regulation or exceeds the permitted use, you will need to obtain permission directly from the copyright holder. 